\title{
Development of an Indirect ELISA with Artificially Synthesized N Protein of PPR Virus
}

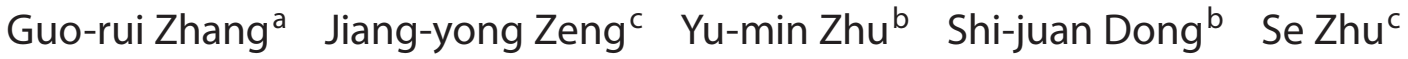 \\ Rui-song Yu ${ }^{b}$ Ciren Duojic Zhi-hai Lei ${ }^{a}$ Zhen Li ${ }^{b}$ \\ ${ }^{a}$ College of Veterinary Medicine, Nanjing Agricultural University, Nanjing, ${ }^{\mathrm{b}}$ Institute of Animal Sciences and \\ Veterinary Medicine and Shanghai Key Laboratory of Agricultural Genetics and Breeding, Shanghai Academy of \\ Agricultural Sciences, Shanghai, and 'Tibet Livestock Research Institute, Tibet Academy of Agricultural and Animal \\ Sciences, Lhasa, China
}

\section{Key Words}

Indirect ELISA - Peste des petits ruminants virus .

Nucleocapsid protein - Nucleocapsid gene ·

Artificial gene synthesis

\begin{abstract}
The full-length gene encoding the nucleocapsid $(\mathrm{N})$ protein of the virus (PPRV) responsible for an outbreak of peste des petits ruminants in Tibet in 2007 was synthesized in two stages using overlapping PCR without the need for viral genomic cDNA as template. The full-length $\mathrm{N}$ gene was successfully expressed in Escherichia coli, and the purified gene product bound to monoclonal antibody raised against PPRV N protein. Furthermore, it was able to replace recombinant B-N antigen as the coating antigen in a commercial ELISA kit prepared with another PPRV strain. Recombinant protein was employed as the coating antigen to develop an indirect ELISA for PPRV antibody detection in the sera of infected small ruminants. Antibody detection was optimal at a 1:200 serum dilution and an antigen concentration of $3.2 \mu \mathrm{g} / \mathrm{ml}$, and the positive threshold (cutoff) value of the assay was 2.18. Analysis of 697 serum samples revealed the sensitivity and specificity of the indirect ELISA to be 96.7 and $96.1 \%$, respectively, compared with a commercially available ELISA test.
\end{abstract}

Copyright ๑ 2011 S. Karger AG, Basel

\section{KARGER}

Fax +4161306 1234

E-Mail karger@karger.ch

www.karger.com
(C) 2011 S. Karger AG, Basel

0300-5526/12/0551-0012\$38.00/0

Accessible online at:

www.karger.com/int

\section{Introduction}

Peste des petits ruminants (PPR) is an acute, highly contagious and economically important viral disease with morbidity and mortality rates as high as 100 and $90 \%$, respectively [1]. The disease, a contagion in goats and sheep, is characterized by severe pyrexia, oculonasal discharges, necrotizing and erosive stomatitis, enteritis and pneumonia [2-4]. PPR was initially epidemic in the Ivory Coast, West Africa [5], and later spread across subSaharan Africa, the Arabian Peninsula and south-west Asia [6]. In July 2007, a PPR outbreak in the southwestern Ngari region of Tibet resulted in heavy goat mortality and huge economic losses to local farmers [7]. PPR is classified as a rapidly spreading and transboundary disease, and is compulsorily notifiable to the Office International des Epizooties [8].

PPR virus (PPRV), the causative agent of PPR, belongs to the genus Morbillivirus of the family Paramyxoviridae [9], has a single-stranded, negative-sense RNA genome encoding eight proteins in the order $3^{\prime}-\mathrm{N}-\mathrm{P} / \mathrm{C} / \mathrm{V}-\mathrm{M}-\mathrm{F}-\mathrm{H}-$ $\mathrm{L}-5^{\prime}$, and is antigenically related to rinderpest virus (RPV) [10]. Although only one PPRV serotype is recognized, PPRV isolates have been classified into four lineages (lineages 1-4) based on molecular epidemiological studies. 


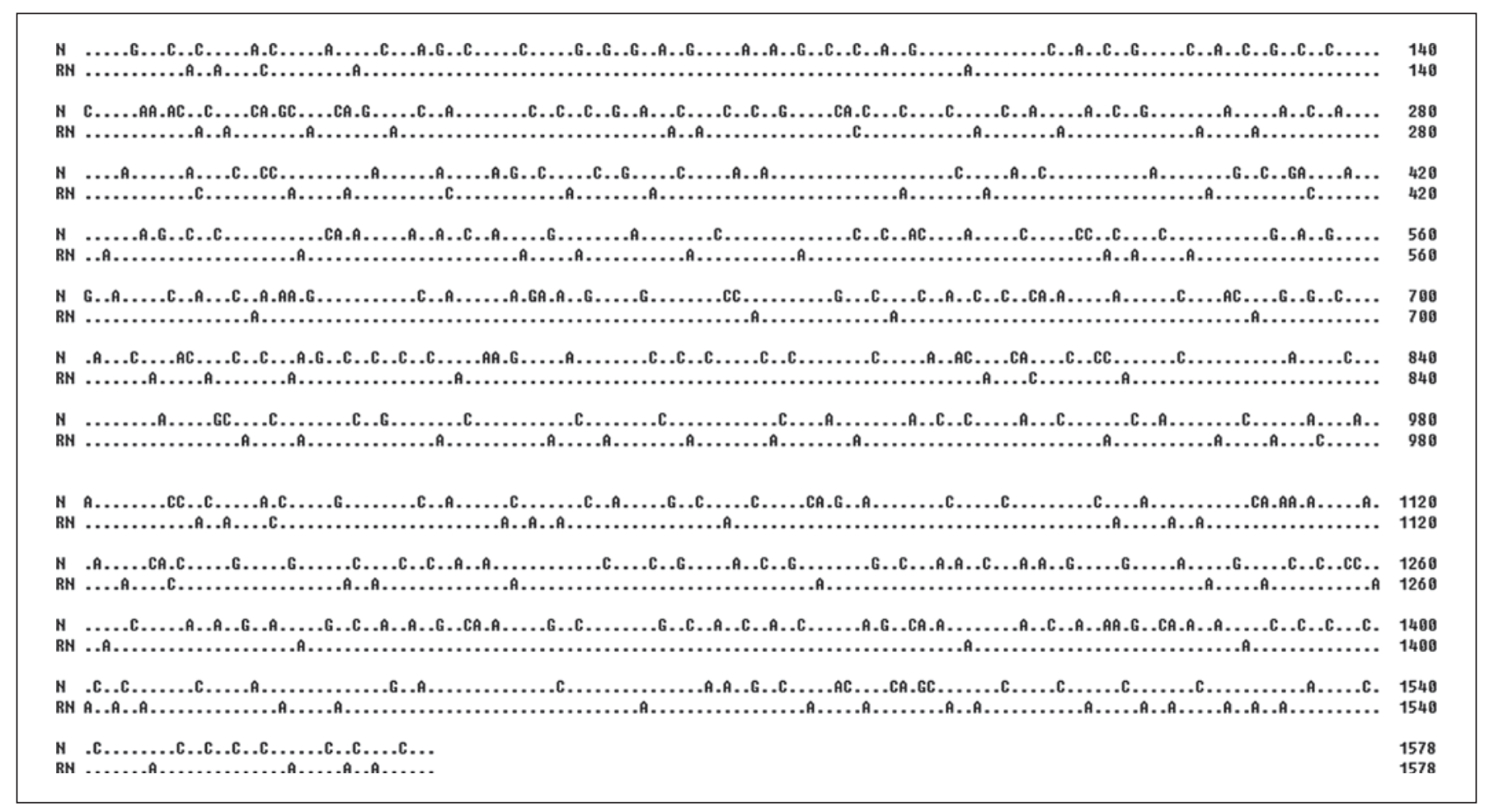

Fig. 1. RN gene sequence. Sequence analysis showed that, although RN exhibited only $71.9 \%$ homology with the nucleotide sequence of the Tibetan PPRV N gene, the encoded amino acid sequences were identical.

Lineages 1-3 have been reported in Africa and lineage 4 in Arabia, Southern Asia and the Middle East. The PPR vaccine viruses Nigeria75/1 and Sungri/96 belong to lineages 1 and 4 , respectively $[11,12]$. Phylogenetic analysis has confirmed that the Tibetan PPRV strain is a lineage 4 virus and is closely related to viruses currently circulating in neighboring countries of southern Asia [7].

In the initial stages of a PPRV epidemic, quarantine measures for isolating infected animals, identified on the basis of actual virus detection or positive serum tests, are essential for controlling the rapid spread of the disease. For this reason, effective diagnostic kits for antigen or antibody detection are required by countries and regions faced with PPRV epidemics. In order to address this need, we set out to develop an ELISA-based system for detecting serum antibody to PPRV. However, since PPRV is a list A animal pathogen in China, we have sought to circumvent the need for virus culture and genome manipulation by artificially synthesizing the complete nucleocapsid (N) gene of Tibetan PPRV and expressing the gene in a prokaryotic system to provide the coating antigen for the ELISA.

Indirect ELISA with Artificially Synthesized N Protein of PPRV

\section{Materials and Methods}

\section{Synthesis of the PPRV N Gene}

The sequence $(1,578 \mathrm{bp})$ of the $\mathrm{N}$ gene of a PPRV isolated during a PPR outbreak in Tibet in 2007 was downloaded from GenBank (FJ905304), and constituent codons were edited for efficient prokaryotic expression [13]. DNAstar (DNASTAR, Inc.) and RNA structure (Rochester University) software were used to analyze the complex secondary structure, and the final sequence was designated as RN (fig. 1).

Twenty primer sets were designed to chemically synthesize RN using overlapping PCR. Primers (Shanghai Jerry Bio, Co., Ltd.) varied between 54 and 63 bp in size (table 1), and adjacent primers overlapped each other by $21 \mathrm{bp}$.

Synthesis consisted of two stages, the first of which was the synthesis of four DNA fragments, between 405 and 414 bp in size, using eight inner primers (template) and two outer primers for each fragment. The PCR reaction system consisted of: PrimeSTAR HS DNA polymerase (Takara) $1 \mu \mathrm{l}, 5 \times$ PrimeSTAR Buffer $\left(\mathrm{Mg}^{2+}\right.$ plus; Takara) $10 \mu \mathrm{l}$, outer oligonucleotides (primer; $30 \mu \mathrm{M}$; primers 1 and 10, primers 11 and 20, primers 21 and 30, primers 31 and 40) $1 \mu \mathrm{l} \times 2$, inner oligonucleotides (template; $3 \mu \mathrm{M}$; primers $2-9$, primers 12-19, primers 22-29, primers 32-39) $1.5 \mu \mathrm{l} \times 8$, and $\mathrm{ddH}_{2} \mathrm{O} 25 \mu \mathrm{l}$. Reaction conditions were as follows: $94^{\circ}$ for $10 \mathrm{~min}$, 25 cycles at $94^{\circ}$ for $30 \mathrm{~s}, 55^{\circ}$ for $15 \mathrm{~s}$ (fragment 1 ), $54^{\circ}$ for $15 \mathrm{~s}$ (fragment 2 ), $56^{\circ}$ for $15 \mathrm{~s}$ (fragment 3 ), $60^{\circ}$ for $15 \mathrm{~s}$ (fragment 4 ), $72^{\circ}$ for 
Table 1. Sequences of primers used for DNA synthesis

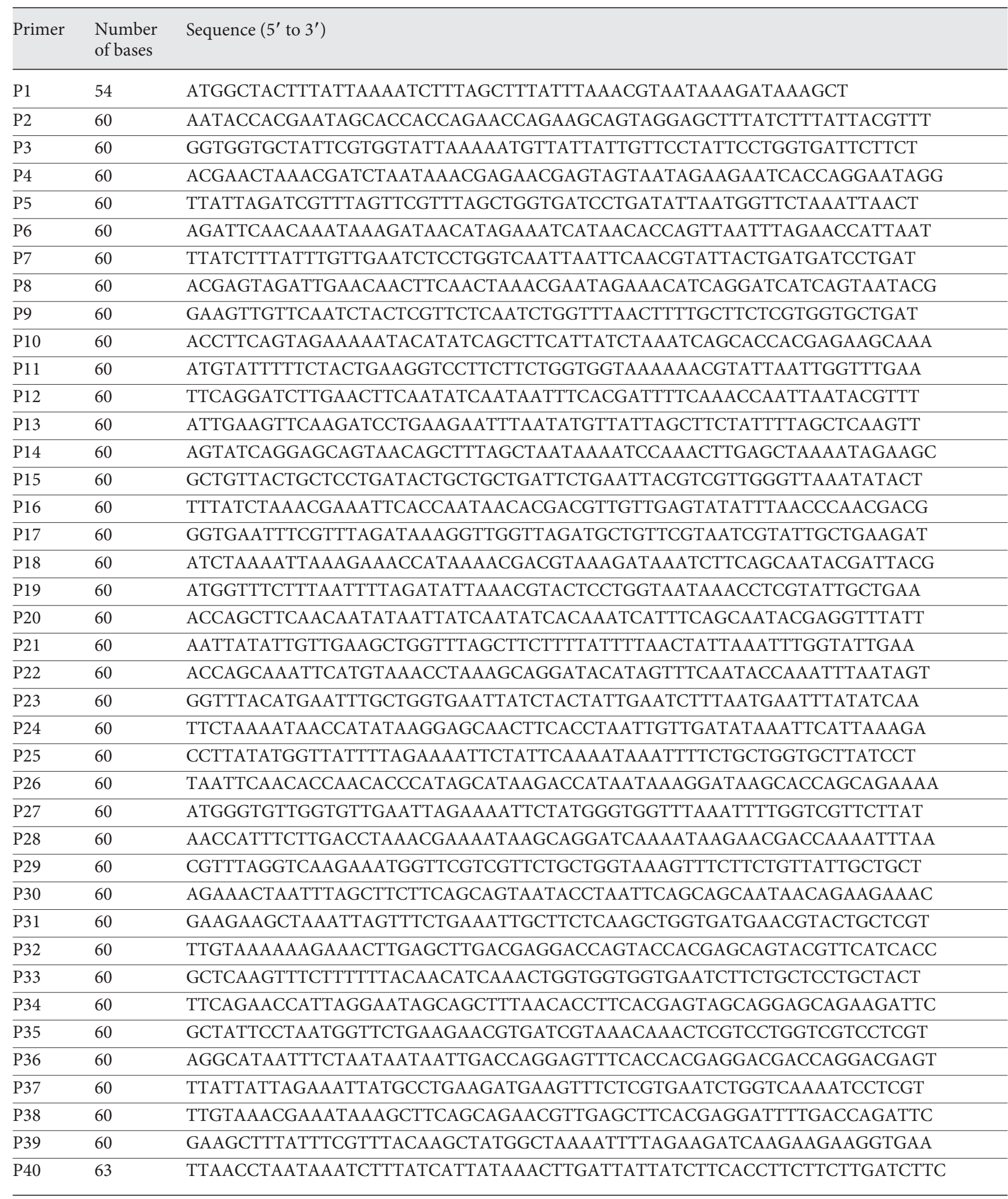


$30 \mathrm{~s}$, then a final extension at $72^{\circ}$ for $10 \mathrm{~min}$. Amplified fragments were purified with a Gel Extraction Kit (Axygen China). In the second stage, the full-length RN gene was obtained using overlapping PCR with the 405-414 bp fragments prepared above. The PCR reaction system consisted of: PrimeSTAR HS DNA polymerase (Takara) $1 \mu \mathrm{l}, 5 \times$ PrimeSTAR Buffer $\left(\mathrm{Mg}^{2+}\right.$ plus; Takara) $10 \mu \mathrm{l}$, outer (primer) oligonucleotides $(30 \mu \mathrm{M}$; primer 1 and primer 40) $1 \mu \mathrm{l} \times 2$, fragment $1-4(100 \mu \mathrm{g} / \mathrm{ml}) 2 \mu \mathrm{l} \times 4$, and $\mathrm{dd}_{2} \mathrm{O}$ $29 \mu \mathrm{l}$. Reaction conditions were as follows: $94^{\circ}$ for $10 \mathrm{~min}, 25$ cycles of $94^{\circ}$ for $30 \mathrm{~s}, 58^{\circ}$ for $15 \mathrm{~s}$, and $72^{\circ}$ for $100 \mathrm{~s}$, followed by a final extension of $72^{\circ}$ for $10 \mathrm{~min}$. Amplified fragments were purified as above, cloned into the simple pMD19-T vector (Takara) and sequenced (Shanghai Shenggong Bio, Co., Ltd.). The vector carrying the targeted fragment was designated as pMD19-T-RN'.

\section{Site-Directed Mutation Correction}

Point mutations in RN were corrected with a set of new complementary primers (N1-N8) containing the modified nucleotide. Firstly, five fragments were amplified by PCR using primer pairs P1/N2, N1/N3, N4/N6, N5/N8 and N7/P40, and pMD19-T$\mathrm{RN}^{\prime}$ as the template (table 2). PCR was then performed with primers $\mathrm{P} 1 / \mathrm{P} 40$ using the products above as the templates, to synthesize the full-length corrected sequence which was then cloned into the simple pMD19-T vector and sequenced.

\section{Construction of the Expression Vector}

The RN gene was fused with the expression vector pET-32a using innovative homologous recombination technology (CloneEZ $^{\mathrm{TM}}$ Kit, GenScript Corporation). Homologous recombination primers carried tags of fifteen bases at their $5^{\prime}$ ends complementary to either side of the vector linearization site. The primers were: PPRNF - 5'AAGGCCATGGCTGATATGGCTACTTTATT AAAATC ${ }^{\prime}$ and PPRNR - 5'GAATTCGGATCCGATTTAACCT AATAAATCTTTAT3'. Amplification conditions were: $4^{\circ}$ for $10 \mathrm{~min}, 25 \mathrm{cycles}$ at $94^{\circ}$ for $30 \mathrm{~s}, 58^{\circ}$ for $15 \mathrm{~s}$ and $72^{\circ}$ for $2 \mathrm{~min}$, with a final extension of $72^{\circ}$ for $10 \mathrm{~min}$. The amplicon and linearized vector were purified using the AxyPrep ${ }^{\mathrm{TM}}$ PCR Cleanup Kit (Axygen China). The expression construct with the RN gene sequence was designated as pET-32a-RN.

\section{Prokaryotic Expression of the Synthesized Recombinant PPRV N Gene}

Fresh Luria-Bertani medium (containing $50 \mu \mathrm{g} / \mathrm{ml}$ penicillin) was inoculated with an overnight culture of Bl21-pET-32a-RN and incubated at $37^{\circ}$ with shaking $(200 \mathrm{rpm})$ until the cells had reached mid-log phase $\left(\mathrm{OD}_{600}=0.6-0.8\right)$. Induction of recombinant protein synthesis was initiated by addition of isopropyl $\beta-D-$ 1-thiogalactopyranoside to a final concentration of $1 \mathrm{mM}$, after which the cell suspension was maintained at $30^{\circ}$ for $4-6 \mathrm{~h}$.

\section{SDS-PAGE and Western Blotting}

Proteins were separated by SDS-PAGE (5\% w/v stacking gel, $10 \%$ w/v resolving gel) and transferred onto a polyvinylidene fluoride membrane (JingKeHongDa Biotechnology, Co., Ltd.) [14], which was then blocked with $3 \%$ (w/v) skimmed milk powder in phosphate-buffered saline (PBS) for $1 \mathrm{~h}$ at room temperature. Expressed recombinant proteins on the membrane were stained by incubation with anti-PPRV $\mathrm{N}$ monoclonal antibody (mAb) and anti-mouse HRPO conjugate (Abgent Primary Antibody Company) with diaminobenzidine as the chromogen. $\mathrm{mAb}$ against $\mathrm{N}$ protein was donated by the China Animal Health and Epidemiology Center.
Table 2. Primers for site-directed correction of mutations

\begin{tabular}{lll}
\hline Primer & Sequence $\left(5^{\prime}\right.$ to $\left.3^{\prime}\right)$ & $\begin{array}{l}\text { Number } \\
\text { of bases }\end{array}$ \\
\hline N1 & CTTTATTTGTTGAATCTCCTGGTC & 24 \\
N2 & GACCAGGAGATTCAACAAATAAAG & 24 \\
N3 & ATTGCTGAAGATTTATCTTTACGTC & 25 \\
N4 & GACGTAAAGATAAATCTTCAGCAAT & 25 \\
N5 & ATTTTGATCCTGCTTATTTTCGTTT & 25 \\
N6 & AAACGAAAATAAGCAGGATCAAAAT & 25 \\
N7 & CTCAAGTTTCTTTTTTACAACATCA & 25 \\
N8 & TGATGTTGTAAAAAAGAAACTTGAG & 25 \\
\hline
\end{tabular}

\section{Purification of Recombinant $N$ Protein}

LB medium $(50 \mathrm{ml})$ was harvested $4 \mathrm{~h}$ after induction and centrifuged at 6,000 $\mathrm{g}$ for $10 \mathrm{~min}$. The pellet was resuspended in $4 \mathrm{ml}$ of guanidium lysis buffer (4 M guanidium hydrochloride, $10 \mathrm{mM}$ $\mathrm{NaH}_{2} \mathrm{PO}_{4}, 10 \mathrm{mM} \mathrm{NaH} \mathrm{PO}_{4}, 500 \mathrm{mM} \mathrm{NaCl}, \mathrm{pH}$ 7.8) by gentle rocking at room temperature for $15 \mathrm{~min}$, followed by three 5 -second bursts of ultrasound (with 10-second pauses in between) while immersed in ice. The lysate was centrifuged at $10,000 \mathrm{~g}$ for $15 \mathrm{~min}$ at $4^{\circ}$, and the supernatant was loaded onto a column containing nickel chelated agarose (Sigma) equilibrated with binding buffer (6 M urea, $10 \mathrm{mM} \mathrm{NaH}_{2} \mathrm{PO}_{4}, 10 \mathrm{mM} \mathrm{NaH}_{2} \mathrm{PO}_{4}, 500 \mathrm{~mm}$ $\mathrm{NaCl}, \mathrm{pH}$ 7.8). The column was washed with binding buffer and washing buffer $\left(20 \mathrm{mM}\right.$ imidazole, $10 \mathrm{mM} \mathrm{NaH}_{2} \mathrm{PO}_{4}, 10 \mathrm{~mm}$ $\mathrm{NaH}_{2} \mathrm{PO}_{4}, 500 \mathrm{mM} \mathrm{NaCl}, \mathrm{pH}$ 7.8), and non-targeted proteins were removed by sequential elution with buffer $\left(10 \mathrm{mM} \mathrm{NaH}_{2} \mathrm{PO}_{4}\right.$, $10 \mathrm{mM} \mathrm{NaH}_{2} \mathrm{PO}_{4}, 500 \mathrm{mM} \mathrm{NaCl}, \mathrm{pH}$ 7.8) containing 100, 200 and $300 \mathrm{~mm}$ imidazole. Recombinant $\mathrm{N}$ protein was eluted with $500 \mathrm{~mm}$ imidazole buffer, and the final concentration of purified protein was estimated colorimetrically with a Micro BCA Protein Assay Kit (Pierce, Rockford, Ill., USA) at $550 \mathrm{~nm}$ using an ELISA reader.

\section{Commercial c-ELISA Kit for Detection of Antibodies} against PPRV

The c-ELISA kit for determining antibodies against PPRV was obtained from Cirad Bios, UPR15, TA A-15/G, Campus International Baillarguet, Montpellier, France. Manipulation of the cELISA was based on the method described by Libeau et al. [15], in which recombinant $\mathrm{B}-\mathrm{N}$ antigen was used as the coating antigen, and serum sample and $\mathrm{mAb}$ competed to combine with $\mathrm{B}-\mathrm{N}$ antigen. Percentage inhibition (PI) values were obtained by detecting the amount of labeled secondary antibody. Samples with cELISA PI values of $\leq 50$ and $>50$ were considered to be PPRV antiserum negative and positive, respectively.

\section{Serum Samples}

Based on the above criteria, 290 serum samples ( 87 goat and 203 sheep) collected from Tibetan farms were PPRV negative, while 209 samples (98 goat and 111 sheep) were PPRV positive. The majority of positive samples $(n=150: 76$ goat, 64 sheep) with PI values of 50-96 were collected from animals raised in an area where vaccination was carried out with live-attenuated PPRV vaccine. Other positive samples $(n=59$; PI $\geq 55)$ were collected from goats $(n=22)$ and sheep $(n=37)$ from nonvaccination areas. Se- 
rum samples $(\mathrm{n}=198$; PI $\leq 40)$ taken from healthy goats raised on Chongming Island (near Shanghai), where there has been no recorded outbreak of PPR, served as negative controls, while samples with a PI value of 91 were designated as strong positive controls. Samples designated as weak positive were prepared by diluting strong positives with 4 volumes of negative serum.

\section{Modified c-ELISA Using RN instead of B-N Antigen}

The antigenic specificity of the recombinant $\mathrm{N}$ protein was determined using a modified c-ELISA in which recombinant PPRV $\mathrm{N}$ protein replaced $\mathrm{B}-\mathrm{N}$. The protocol was otherwise identical to that used for the commercial c-ELISA kit, and wells with no serum served as the mAb control (zero percent competition). Serum controls included strong positive, weak positive and negative samples.

\section{Indirect ELISA Using Artificially Synthesized Recombinant}

PPRV N Protein as the Coating Antigen

Antigen was dissolved in carbonate/bicarbonate buffer solution (0.05 M, pH 9.6) and coated onto 96-well plates (Maxisorp F96; Nunc, Kamstrup, Denmark) by incubating overnight at $4^{\circ}$. After washing with PBS-T buffer (0.002 M PBS containing $0.05 \%$ Tween 20), the wells were blocked with $250 \mu$ l blocking buffer (PBS-T containing 3\% lactalbumin hydrolysate) for $60 \mathrm{~min}$. After further washing, $50 \mu \mathrm{l}$ diluted serum was added and the wells were again incubated for $60 \mathrm{~min}$ to allow the antigen and first antibody to combine. The plates were washed three times and, following addition of either anti-goat-HRPO (Immunology Consultants Laboratory) or anti-sheep-HRPO (Santa Cruz Biotechnology) conjugate (diluted 1:8,000 with blocking buffer in both cases), were incubated at $37^{\circ}$ for 30 min to allow the primary and secondary antibodies to combine. Substrate solution $(1 \mathrm{mg} / \mathrm{ml}$ TMB containing $4 \mu \mathrm{l} 3 \% \mathrm{H}_{2} \mathrm{O}_{2}$ ) was dispensed into each well, and the color reaction was allowed to develop for $10 \mathrm{~min}$ in the dark. After termination of the reaction, absorbance values at $450 \mathrm{~nm}$ were measured with the FAO/IAEA EDI software [16].

\section{Optimization of the Prototype Indirect ELISA}

Dilutions of antigen and antibodies for optimization of the prototype indirect ELISA (i-ELISA) were determined by the standard checkerboard titration procedure. Antigen concentrations were $12.8,6.4,3.2,1.6,0.8$ and $0.4 \mu \mathrm{g} / \mathrm{ml}$, and serum dilutions (negative serum: c-ELISA PI $\leq 20$; positive serum c-ELISA PI $\geq 75$ from PPR-vaccinated animals) were 1:50, 1:100, 1:200 and 1:400. Antigen and serum dilutions that gave the maximum positive/negative $(\mathrm{P} / \mathrm{N})$ ratio were selected. The reaction temperature, time and other conditions were selected from the index of $\mathrm{P} / \mathrm{N}$ values [17].

\section{Determination of Cutoff Values}

Cutoff values of the prototype i-ELISA were determined as the mean +2 standard deviations (SDs) and the mean +3 SDs, which were derived from the $\mathrm{P} / \mathrm{N}$ values of 198 negative Chongming samples. Diagnostic sensitivity and specificity were calculated using the two cutoff values. Positive and negative controls for i-ELISA usually gave absorbance values of $\geq 0.6$ and $\leq 0.2$, respectively, and the test was repeated when values fell outside this range.

\section{Evaluation of i-ELISA Sensitivity and Reproducibility}

The sensitivity of the i-ELISA was evaluated using strongly positive sera $(\mathrm{PI}=91)$ serially diluted (twofold) with negative goat serum $(\mathrm{PI} \leq 15)$. Operating conditions were selected on the basis of the optimization data obtained above.
Twenty sera were selected to evaluate the reproducibility of the assay. For each sample, the coefficient of variation (CV) was calculated between plates (inter-assay variation) and within the same plate (intra-assay variation). Each sample was tested using four different plates on different occasions to determine the interassay $\mathrm{CV}$, and four replicates within each plate were used to calculate the intra-assay CV.

\section{Results}

\section{Cloning of the RN Gene and Mutation Correction}

Partial and full-length RN genes were obtained by overlapping PCR, which yielded four smaller $(405,411$, 411 and $414 \mathrm{bp}$ ) and one larger (1,578 bp) DNA fragments.

Sequence analysis of the RN revealed four point mutations generated during amplification, which were $245 \mathrm{G}$ redundancy, $679 \mathrm{C} \rightarrow \mathrm{T}, 1079 \mathrm{C} \rightarrow \mathrm{A}$, and $1256 \mathrm{~T} \rightarrow \mathrm{C}$. A full-length corrected sequence was prepared using the two-stage procedure described in 'Materials and Methods', and successful elimination of the mutations was confirmed by cloning and sequencing.

\section{Expression and Purification of PPRV N Protein}

A protein with a molecular weight of $75 \mathrm{kDa}$, which corresponded well with the presumed recombinant PPRV $\mathrm{N}$, was obtained through isopropyl $\beta$-D-1-thiogalactopyranoside induction of transformed Escherichia coli cells and was confirmed as PPRV N antigen by Western blotting (fig. 2). The protein was located mainly in the soluble phase of the cell lysate and, after elution from nickel-chelated agarose columns, was $\sim 95 \%$ pure (fig. 3). Yields of up to $10.9 \mathrm{mg} / \mathrm{l}$ culture were achieved.

\section{Modified c-ELISA Substituting B-N with RN}

Twelve samples were tested in parallel by using the two antigens. The corresponding PI values differed by less than $5 \%$ in seven sample sets, and between 5 and $15 \%$ in the remaining five (fig. 4).

\section{Working Concentrations of Antigen and Serum for i-ELISA}

In the checkerboard titration tests, the maximum difference in the OD values for positive and negative sera was obtained with a 1:200 dilution of serum at an antigen concentration of $3.2 \mu \mathrm{g} / \mathrm{ml}$. Under these conditions, the $\mathrm{P} / \mathrm{N}$ value was 5.37 at a 1:8,000 dilution of anti-goat/ sheep-HRPO conjugate (fig. 5). 


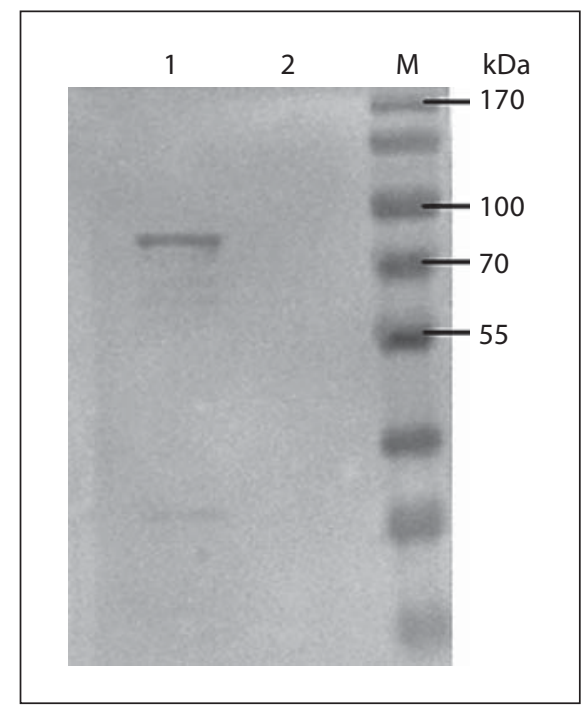

Fig. 2. Western blot analysis of soluble lysate. Lane 1: soluble lysate of Bl21-32a-RN (5 h). Lane 2: lysate from induced Bl21 which carried the empty vector. Lane M: prestained molecular weight protein markers.

Table 3. Effect of different cutoff values on sensitivity and specificity of i-ELISA

\begin{tabular}{lll}
\hline & Cutoff value & \\
\cline { 2 - 3 } & $2.18($ mean +2 SDs $)$ & $2.33($ mean +3 SDs $)$ \\
\hline Sensitivity & $96.7 \%(202 / 209)$ & $94.7 \%(198 / 209)$ \\
Specificity & $96.1 \%(469 / 488)$ & $97.8 \%(477 / 488)$ \\
\hline
\end{tabular}

Validation and Repeatability of $i$-ELISA

For the twenty selected sera, the inter-assay CV ranged from 1.9 to $5.8 \%$, and the intra-assay $\mathrm{CV}$ ranged from 1.4 to $5.0 \%$.

\section{Cutoff Values, Specificity and Sensitivity of i-ELISA}

The mean P/N value for the $198 \mathrm{PPRV}$-negative control sera taken from healthy goats raised on Chongming Island was 1.875 with an SD of 0.152. Therefore, cutoff values were set to 2.18 (mean +2 SDs) and 2.33 (mean +3 SDs).

Sensitivity and specificity values were 96.7 and $96.1 \%$, respectively, at the 2.18 cutoff level, and 94.7 and $97.8 \%$, respectively, at the 2.33 cutoff level compared with a commercially available ELISA test (table 3 ).

Indirect ELISA with Artificially Synthesized N Protein of PPRV

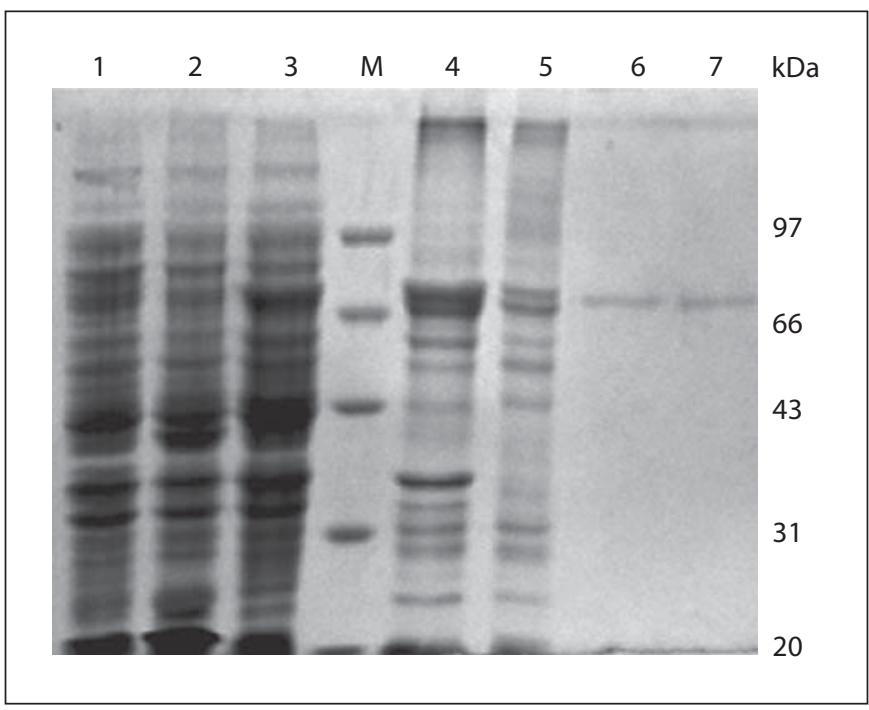

Fig. 3. SDS-PAGE analysis of expressed proteins. Lane 1: soluble lysate of Bl21-32a. Lane 2: soluble lysate of Bl21-32a-RN (0 h). Lane 3: lysate of Bl21-32a-RN (5 h). Lanes 4-7: protein eluted from the nickel-chelated agarose column by 100, 200, 300 and $500 \mathrm{~mm}$ imidazole, respectively. M: low-molecular-weight protein markers.

The i-ELISA P/N values of 697 serum samples that had been designated as either positive or negative by c-ELISA are shown in figure 6.

$\mathrm{P} / \mathrm{N}$ values of a strong positive serum sample gradually decreased with increasing dilution with negative serum and were negatively correlated with the log of the dilution (fig. 7). The maximum dilution giving a positive result was $1: 12,800$.

\section{Discussion}

PPR is recognized as a major constraint in augmenting small ruminant productivity in regions and countries, including parts of Africa, the Middle East, India and China, where the disease is epidemic. In view of the economic importance of the disease, priority has been given to effective serological surveillance of PPRV. Since ELISA is widely accepted as a highly sensitive and efficient method for detecting different kinds of antigen or antibody, our aim was to develop an i-ELISA for the serological surveillance of PPRV in China.

Among the structural proteins of morbilliviruses, the $\mathrm{N}$ protein is strongly immunogenic and has a highly conserved structure [18]. The protein is expressed at high levels in infected cells [19], and has different epitopes that can be used for identifying PPRVs of different lineages.

Intervirology 2012;55:12-20 


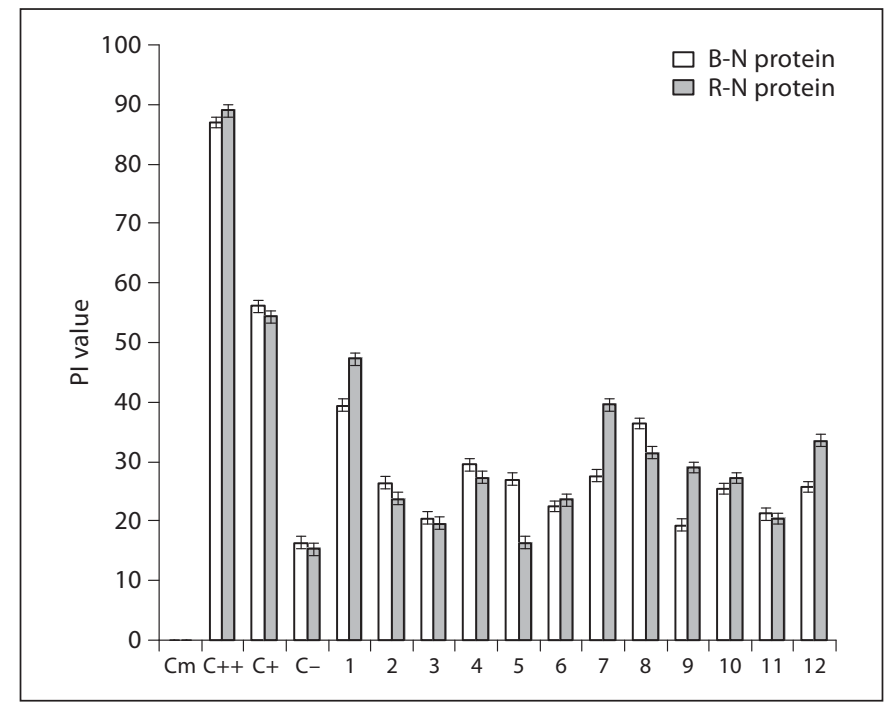

Fig. 4. Comparison of c-ELISA $\mathrm{P} / \mathrm{N}$ values using $\mathrm{B}-\mathrm{N}$ or $\mathrm{R}-\mathrm{N}$ as coating antigen. $1-12$ = goat serum samples; $\mathrm{Cm}=\mathrm{mAb}$ control; $\mathrm{C}++=$ strong positive serum control; $\mathrm{C}+=$ weak positive serum control; $\mathrm{C}-=$ negative serum control. Differences in the two PI values were $<5 \%$ for samples $2-4,6,8,10$ and 11 , and between 5 and $15 \%$ for the remainder.

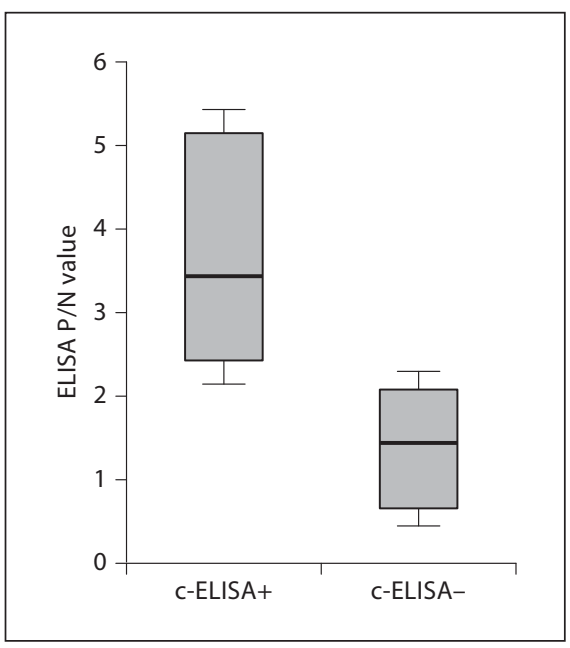

Fig. 6. Reassessment of 209 positive and 488 negative samples with i-ELISA. Note: Data are based on a cutoff value of 2.18 .

Therefore, we have employed the N protein of PPRV/China/Tibet/Geg/07-30 to develop an i-ELISA for detecting antibody against PPRV. Previously, recombinant N proteins of the virulent Kabete $\mathrm{O}$ strain of RPV [20] and Nigeria75/1 PPRV [3] were expressed in baculovirus, and used in ELISAs to distinguish between vaccinated and

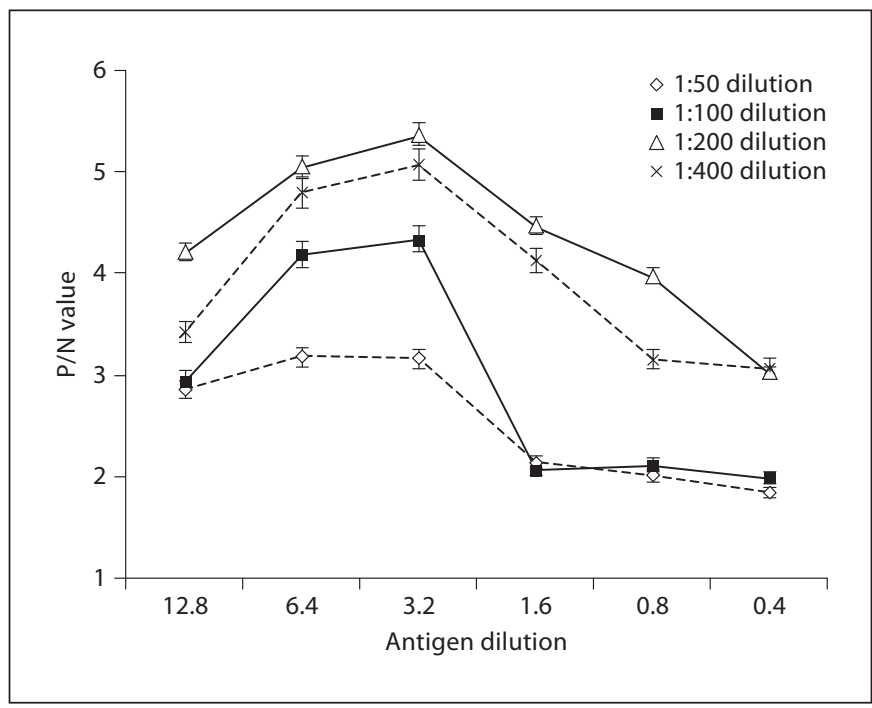

Fig. 5. Checkerboard titration of antigen and sera. The maximum $\mathrm{P} / \mathrm{N}$ value of 5.37 was obtained between positive and negative serum samples at a coating antigen concentration of $3.2 \mu \mathrm{g} / \mathrm{ml}$ and a 1:200 dilution of the serum sample.

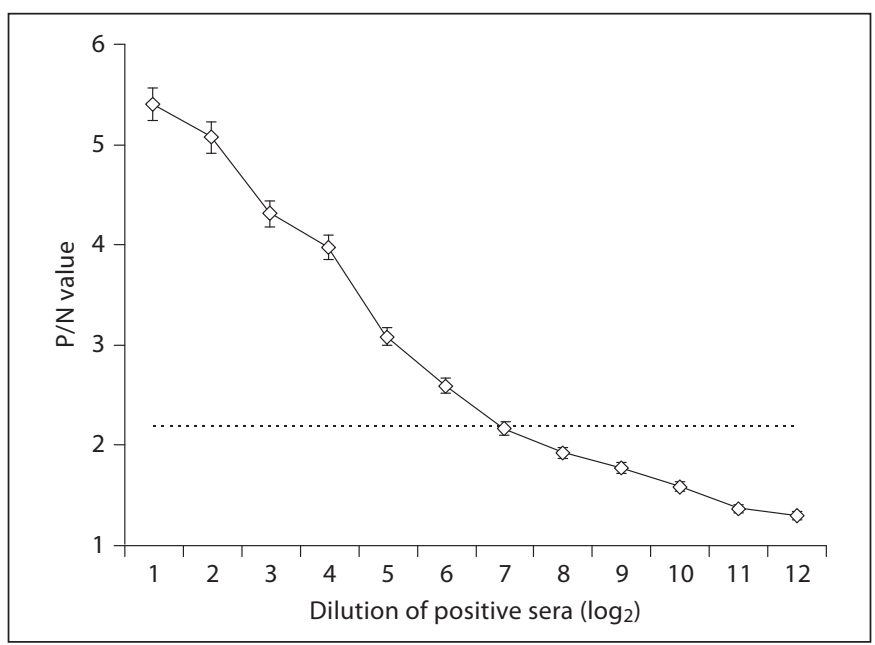

Fig. 7. Effect of dilution with negative serum on the reactivity of a convalescent serum with antigen. Dotted line shows positive/ negative cutoff.

RPV-infected animals, and for serological diagnosis of PPR, respectively.

Genes encoding $\mathrm{N}$ protein have been isolated from several different PPRV strains and used in the development of PPRV serological detection methods [8, 19, 21]. However, since access to these genes also required ma- 
nipulation of the PPRV, we have adopted a novel approach in order to reduce the potential risks associated with using viral material. In our research, we have used information relating to PPRV/China/Tibet/Geg/07-30 accessible in the databases and advanced molecular biological tools to artificially synthesize the entire $\mathrm{N}$ gene of this PPRV strain. Several oligonucleotide-based methods for the synthesis and assembly of long DNA sequences have been described in recent years including the PCR-based thermodynamically balanced inside-out procedure [22], successive PCR [23], PCR-based two-step DNA synthesis (PTDS) [24], and PCR-based accurate synthesis [25]. In this study, we used the PTDS method to successfully synthesize the entire $\mathrm{N}$ gene of PPRV. However, as this is a PCR-based procedure, DNA polymerase proofreading defects are inherent and four point mutations occurred during synthesis. These were readily corrected adopting a similar experimental approach and using the initially acquired but defective full-length 1,578-bp DNA fragment as the template.

Different strategies were adopted for effective R-N expression and gene product purification, including the use of prokaryotic preferred codons and addition of a 6-his tag at the N-terminal of the recombinant protein. Substitution of B-N with R-N in tests conducted with a commercial ELISA kit resulted in similar $\mathrm{P} / \mathrm{N}$ values $(<5 \%$ difference) for seven of the test samples, but bigger differences (5-15\%) in the case of five other sera. This discrepancy may be attributable to the fact that the two $\mathrm{N}$ proteins (from the Tibetan strain and Nigeria75-1 strain, respectively), although $95.6 \%$ homologous in terms of amino acid sequence, had different epitopes with different affinities for the serum sample.

Using the cutoff value obtained using the mean of 198 negative samples plus $2 \times$ the SD, the assay exhibited a high degree of specificity and sensitivity with inter-assay and intra-assay CVs less than 4.3 and 5.0\%, respectively. These data were confirmed in a twofold serial dilution test in which a strong positive serum sample was serially diluted with PPR-negative goat serum $(\mathrm{PI}=17)$ prior to testing with i-ELISA. Positive results were recorded with dilutions as high as 1:12,800.

In conclusion, we describe an efficient procedure for obtaining coating antigen for use in an i-ELISA of PPRV antibody among goats or sheep that eliminates the need for virus culture and reduces the bio-risk posed by virusdependent manipulation. Our data confirmed the similar antigenic nature of the native and recombinant proteins, and the suitability of the latter for use in i-ELISA-based PPRV surveillance.

\section{Acknowledgements}

This work was sponsored by the Shanghai Pujiang Program and the Shanghai Project for Collaboration with Chinese Western Areas (No. 083958013). We thank Shi-biao Yang from the Yunnan Academy of Animal Science and Veterinary Medicine and Zhiliang Wang and Xiao-dong Wu from the Chinese Animal Epidemic Disease Center for their kind help and suggestions relating to sample detection and analysis. We also thank Ai-sheng Xiong and Quan-hong Yao of the Biotechnological Institute, SAAS, for help with the gene synthesis, and Dr. John Buswell, Institute of Edible Fungi, SAAS, for linguistic revision of the manuscript.

\section{References}

$>1$ Abu Elzein EM, Hassanien MM, Al-Afaleq AI, Abd Elhadi MA, Housawi FM: Isolation of peste des petits ruminants from goats in Saudi Arabia. Vet Rec 1990;127:309-310.

$\checkmark 2$ Diallo A, Barrett T, Barbron M, Subbarao SM, Taylor WP: Differentiation of rinderpest and peste des petits ruminants viruses using specific cDNA clones. J Virol Methods 1989; 23:127-136.

3 Ismail TM, Yamanaka MK, Saliki JT, ElKholy A, Mebus C, Yilma T: Cloning and expression of the nucleoprotein of peste des petits ruminants virus in baculovirus for use in serological diagnosis. Virology 1995;208: 776-778.
${ }_{4}$ Jones L, Giavedoni L, Saliki JT, Brown C, Mebus C, Yilma T: Protection of goats against peste des petits ruminants with a vaccinia virus double recombinant expressing the $\mathrm{F}$ and $\mathrm{H}$ genes of rinderpest virus. Vaccine 1993;11:961-964.

5 Gargadennec L, Lalanne A: La peste des petits ruminants. Bull Serve Zootech Epizoot Afr Occid Fr 1942;5:16-21.

$\checkmark 6$ Taylor WP: The distribution and epidemiology of peste des petits ruminants. Prev Vet Med 1984;2:157-166.

-7 Wang Z, Bao J, Wu X, Liu Y, Li L, Liu C, Suo L, Xie Z, Zhao W, Zhang W: Peste des petits ruminants virus in Tibet, China. Emerg Infect Dis 2009;15:299-301.
8 Bodjo SC, Kwiatek O, Diallo A, Albina E, Libeau G: Mapping and structural analysis of B-cell epitopes on the morbillivirus nucleoprotein amino terminus. J Gen Virol 2007; $88: 1231$.

9 Regenmortel MHV, Fauquet CM, Bishop DHL, Carstens EB, Estes MK, Lemon SM, Maniloff J, Mayo MA, McGeoch DJ, Pringle CR: Virus Taxonomy Classification and Nomenclature of Viruses, Seventh Report of the International Committee on Taxonomy of Viruses. San Diego, Academic Press, 2000.

10 Gibbs EP, Taylor WP, Lawman MJP, Bryant $\mathrm{J}$ : Classification of peste des petits ruminants virus as the fourth member of the genus Morbillivirus. Intervirology 1979;11:268-274. 
-11 Dhar P, Sreenivasa BP, Barrett T, Corteyn M, Singh RP, Bandyopadhyay SK: Recent epidemiology of peste des petits ruminants virus (PPRV). Vet Microbiol 2002;88:153-159.

-12 Shaila MS, Shamaki D, Forsyth MA, Diallo A, Goatley L, Kitching RP, Barrett T: Geographic distribution and epidemiology of peste des petits ruminants viruses. Virus Res 1996;43:149-153.

13 Saier MH: Differential codon usage: a safeguard against inappropriate expression of specialized genes? FEBS Lett 1995;362:1-4.

14 Burnette WN: 'Western blotting': Electrophoretic transfer of proteins from sodium dodecyl sulfate-polyacrylamide gels to unmodified nitrocellulose and radiographic detection with antibody and radioiodinated protein A. Anal Biochem 1981;112:195-203.

15 Libeau G, Prehaud C, Lancelot R, Colas F, Guerre L, Bishop DHL, Diallo A: Development of a competitive ELISA for detecting antibodies to the peste des petits ruminants virus using a recombinant nucleoprotein. Res Vet Sci 1995;58:50-55.
16 Jeggo $\mathrm{MH}$, Anderson J: FAO/IAEA External Quality Assurance Programme for the FAO/IAEA Competitive ELISA Results in 1992. The Sero-Monitoring of Rinderpest throughout Africa: Phase II. Vienna, International Atomic Energy Agency, 1992, pp 9-21.

17 Bakheit MA, Schnittger L, Salih DA, Boguslawski K, Beyer D, Fadl M, Ahmed JS: Application of the recombinant Theileria annulata surface protein in an indirect ELISA for the diagnosis of tropical theileriosis. Parasitol Res 2004;92:299-302.

18 Francki RIB, Fauquet CM, Knudson DL, Brown F: Classification and Nomenclature of Viruses: Fifth Report of the International Committee on Taxonomy of Viruses. New York, Springer, 1991.

19 Diallo A, Barrett T, Barbron M, Meyer G, Lefevre PC: Cloning of the nucleocapsid protein gene of peste-des-petits-ruminants virus: relationship to other morbilliviruses. J Gen Virol 1994;75:233-237.

20 Ismall T, Ahmad S, D’Souza-Ault M, Bassiri M, Saliki J, Mebus C, Yilma T: Cloning and expression of the nucleocapsid gene of virulent Kabete $\mathrm{O}$ strain of rinderpest virus in baculovirus: use in differential diagnosis between vaccinated and infected animals. Virology 1994;198:138-147.
21 Yadar V, Balamurugan V, Bhanuprakash V, Sen A, Bhanot V, Venkatesan G, Riyesh T, Singh RK: Expression of Peste des petits ruminants virus nucleocapsid protein in prokaryotic system and its potential use as a diagnostic antigen or immunogen. J Virol Methods 2009;162:56-63.

22 Gao X, Yo P, Keith A, Ragan TJ, Harris TK: Thermodynamically balanced inside-out (TBIO) PCR-based gene synthesis: a novel method of primer design for high-fidelity assembly of longer gene sequences. Nucleic Acids Res 2003;31:e143.

23 Xiong AS, Yao QH, Peng RH, Li X, Fan HQ, Guo MJ, Zhang SL: Isolation, characterization, and molecular cloning of the cDNA encoding a novel phytase from Aspergillus niger 113 and high expression in Pichia pastoris. J Biochem Mol Biol 2004;37:282-291.

24 Xiong AS, Yao QH, Peng RH, Li X, Fan HQ, Cheng ZM, Li Y: A simple, rapid, high-fidelity and cost-effective PCR-based two-step DNA synthesis method for long gene sequences. Nucleic Acids Res 2004;32:e98.

25 Xiong AS, Yao QH, Peng RH, Duan H, Li X, Fan HQ, Cheng ZM, Li Y: PCR-based accurate synthesis of long DNA sequences. Nat Protoc 2006;1:791-797. 